\title{
Which Country is More Effective in Science Teaching? Evidence from PISA 2015 as a Secondary School Assessment Tool
}

\author{
Gökhan Ilgaz ${ }^{1}$ \\ Menekșe Eskici ${ }^{2}$ \\ Levent Vural ${ }^{3}$ (D)
}

${ }^{1,3}$ Faculty of Education, Educational Sciences Department, Dr. Trakya University, Turkey Email:gokhani@trakya.edu.tr

smail:leventvural@trakya.edu.tr

${ }^{2}$ Faculty of Science and Art, Educational Sciences Department, Dr. Kirklareli University, Turkey

Email:menekeskici@hotmail.com

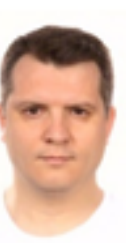

\begin{abstract}
The aim of this study is to determine how effectively different countries use educational inputs in the process of science education. The study is in the descriptive model and the data is derived from the PISA 2015 data set, which provides information to countries on secondary education programs. Data from 70 countries, including Turkey, were used in the study. The effectiveness of Turkey in the process of science teaching in secondary education has been compared with other countries and suggestions have been made to increase the effectiveness of secondary education science teaching. The data for this study are grouped into training inputs and training outputs. "Student behaviour hindering learning", "teacher behaviour hindering learning", "shortage of educational material", "shortage of educational staff", "professional development", "teachers participation", "curricular development", "total number of science teachers at school", "index science-specific resources (sum)" were defined as the educational inputs. The science achievements of students have been taken into account in determining which countries have more effective management of educational inputs accepted in this study. Secondary scholl level education inputs while nearby countries respectively to use effectively Slovakia (97.30\%), Slovenia (91.16\%), Brazil (90.50\%), Turkey (89.75\%), Finland (84.65\%), Greece (83.31\%), Denmark ( 83.25\%), and Czech Republic (80.61\%). education outcomes in Turkey is ranked as $20^{\text {th }}$ in science teaching secrets to use it effectively.
\end{abstract}

Keywords: Secondary school, Curriculums, Effective science teaching, PISA 2015, Data envelopment, Training inputs and training outputs.

Citation | Gökhan Ilgaz; Menekşe Eskici; Levent Vural (2019). Which Country is More Effective in Science Teaching? Evidence from PISA 2015 as a Secondary School Assessment Tool. Asian Journal of Education and Training, 5(2): 349-361. History:

Received: 12 February 2019

Revised: 20 March 2019

Accepted: 29 April 2019

Published: 24 July 2019

Licensed: This work is licensed under a Creative Commons

Attribution 3.0 License (c) $)$

Publisher: Asian Online Journal Publishing Group
Acknowledgement: All authors contributed to the conception and design of the study.

Funding: This study received no specific financial support.

Competing Interests: The authors declare that they have no conflict of interests.

Transparency: The authors confirm that the manuscript is an honest, accurate, and transparent account of the study was reported; that no vital features of the study have been omitted; and that any discrepancies from the study as planned have been explained.

Ethical: This study follows all ethical practices during writing.

\section{Contents}

1. Introduction

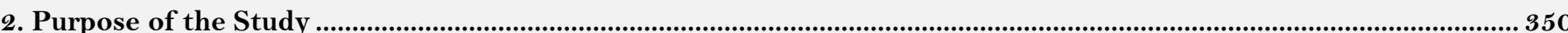

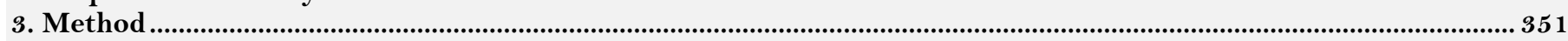

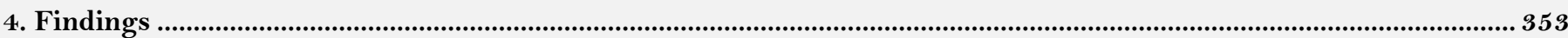

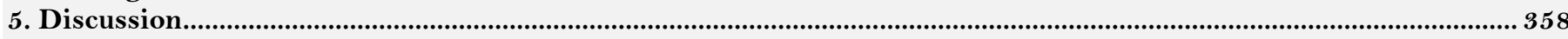

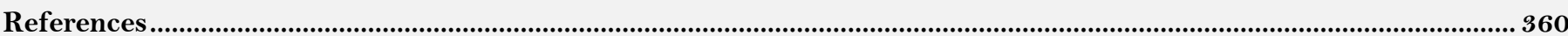




\section{Contribution of this paper to the literature}

This study contributes to the existing literature by determining how effectively different countries use educational inputs in the process of science education.

\section{Introduction}

Science is more than merely a part of daily life; it is daily life itself. Subjects such as stirring sugar in tea to make it dissolve faster, the need to take plugs out of sockets during lightning storms, how natural events such as rain and snow occur, and the harm caused to the body by not drinking enough water, all fall under the scope of science. Considered from this point of view, not only is it true that for humans, who lead their lives as part of nature, it is impossible to live apart from science, it is also a fact that if they are not sufficiently equipped with regard to science, their lives will be made equally difficult. The importance of science stems from the fact that it encompasses not only the most basic activities in daily life, but also much more complex subjects such as the production of technology, increasing efficiency in the use of natural resources, and discovering the keys to a longer life. Developments in the field of science and reflecting them into daily life are the most significant indicators of the establishment of modern life in society and of the progress of nations. Therefore, the teaching of science plays a key role in an individual's personal development as well as in the advancement of nations.

Scientific knowledge is a lesson that is so much a part of life that Davis et al. (2006) stress that a science education that focuses on real challenges is the main reason for success. It can be said that science and technology lessons carried out in a social context change attitudes towards science in a positive way and support the creation of the basis for a solid scientific understanding. The best way to increase students' interest in science is to associate the lesson subjects to daily life, since it is possible for students to perceive the benefits of science when they see its reflection in daily life (Bennett et al., 2007; Maltese et al., 2014; Sheldrake et al., 2017). If attitudes towards science become negative and if students' concerns about the subject of science affect their career choices and lead them in other directions, this will be a worrying situation for developments in the field of science. Therefore, endearing students to science builds the mainframe for their future achievements related to science (Osborne et al., 2003). It would not be wrong to say that attitudes towards science form the source of skills related to scientific knowledge, technological developments and science. The problem here is that although science is so important, attitudes towards science are low. Conducted studies have shown that attitudes towards science are low because of negative experiences occurring in science lessons (Mulholland and Wallace, 1996; Palmer, 2001). Based on this, it can be said that the science education process needs to be organised in such a way as to affect students' attitudes towards science in a positive way.

It is argued that the approach to science education should be regarded as "education through science" rather than "science through education" (Holbrook and Rannikmae, 2007). The real sine qua non of science education is that students should learn science by experiencing it and not by rote. The place of the laboratory environment in science education is indisputable. The opportunity for students to learn by doing and experiencing is a great chance for those students' science learning (Hodson, 1988; Kirschner et al., 2006). In addition to these, the design of a science education learning environment that includes activities focusing on skills like experimentation and reasoning, that is supported by visuals, and in which primary sources or models are used, is recommended (Evagorou et al., 2015).

The need to consider the problem of how science education should be taught, rather than what should be taught, is pointed out. Science education is possible not merely by learning basic knowledge, but with the application of that knowledge. Baeten et al. (2010) state that education conducted with a student-centred approach supports deep learning. Success in science education is related to experiencing scientific knowledge by doing research (Clermont et al., 1994; Bybee, 2014; Osborne, 2014). Moreover, there are indicators regarding the fact that conducting science education in a collaborative way will contribute to students' cognitive development as a result of their mutual interaction and sharing of ideas (Koretsky et al., 2019). It is emphasised that learning and teaching science lessons in a more collaborative way will be beneficial (Huppert et al., 2002).

Controversial findings related to the factors influencing success in science are found in the literature. In a study made by Stohr-Hunt (1996) it was found that success in science classes of students who had more experience was greater than that of students with less experience. In a study conducted by Cairns and Areepattamannil (2019) it was determined that based on the PISA data, inquiry-based science education was significantly negatively correlated with science success, whereas inquiry-based science education was significantly positively correlated with dispositions towards science such as interest in and enjoyment of learning science, instrumental and futureoriented motivation for science, and science self-esteem. Using the TIMSS 2015 data for Norway, Teig et al. (2018) concluded in their study that inquiry-based science teaching on a large scale had a negative effect on science achievement, a fact which supports the findings made by Cairns and Areepattamannil (2019).

Undoubtedly, there are various factors affecting academic success. The basic factors that affect students' academic success are considered to be teacher competencies (Rockoff, 2004; Aaronson et al., 2007; Rothstein, 2010; Harris and Sass, 2011) undesirable student behaviours (Durán-Narucki, 2008; Maxwell, 2016) school facilities (Gislason, 2010; Rivera and Lopez, 2019) and the school's relationship with parents (Hill and Taylor, 2004; Jeynes, 2007). The same factors can be listed as determinants of success in the subject of science. In the PISA 2015 report, the educational inputs affecting science achievement were defined as "student behaviours preventing learning", "teacher behaviours preventing learning", "lack of educational materials", "lack of teaching staff", "professional development", "teacher participation", "curriculum development", "total number of science teachers in school" and "science-specific resource index (total)".

\section{Purpose of the Study}

In an age in which development in science technology is taken as the basis as the most important indicator of countries' development, the process of scientific knowledge production in universities has also gained importance. The education of individuals who can produce scientific knowledge is also of equal importance. When considering 
that the most determining factor for success in the education process is readiness, it can be regarded as an undisputable fact that possessing competence in science in the secondary education period has an impact on educating individuals who will be able to produce scientific knowledge in higher education. Based on this, it can be concluded that the effectiveness of science teaching carried out during the secondary education process is very important for the development of nations. The more successfully science education is conducted during the secondary education process and the higher the level of readiness of students sent into higher education, the more the levels of countries' scientific knowledge production and of their technological development will increase. Therefore, it is considered important to determine the effect on success of the educational inputs that will determine the effectiveness of science teaching in secondary school curricula. The aim of this study is to determine how efficiently different countries use educational inputs in the science teaching process.

\section{Method}

\subsection{Research Model}

With the aim of evaluating the relative efficiency of the inputs or efforts put in by countries, using these countries' PISA 2015 Science scores as outputs, this study was designed according to the survey model.

\subsection{Study Group}

The study was conducted with data obtained from schools in 70 countries/regions that participated in the PISA 2015 study. For the analysis, in order to remove negative numbers and to facilitate interpretation, the data were converted into z scores. Since there were outliers in the input scores for Tunisia and China (Beijing-ShanghaiJiangsu-Guangdong), these were removed. It was seen that there were no outliers in the $\mathrm{z}$ scores obtained for the remaining 68 countries. In the correlation analysis conducted, it was determined whether or not there was multicollinearity, and the study was carried out with 68 countries. The distributions of the countries included in the study are shown in Table 1 .

Table-1. Countries and numbers of schools included in the study.

\begin{tabular}{|c|c|c|c|c|c|}
\hline Countries & Frequency & $\%$ & Countries & Frequency & $\%$ \\
\hline Albania & 230 & 1.32 & Latvia & 250 & 1.43 \\
\hline Algeria & 161 & 0.92 & Lithuania & 311 & 1.78 \\
\hline Australia & 758 & 4.34 & Luxembourg & 44 & 0.25 \\
\hline Austria & 269 & 1.54 & China (Macao) & 45 & 0.26 \\
\hline Belgium & 288 & 1.65 & Malta & 59 & 0.34 \\
\hline Brazil & 841 & 4.81 & Mexico & 275 & 1.57 \\
\hline Bulgaria & 180 & 1.03 & Moldova & 229 & 1.31 \\
\hline Canada & 759 & 4.34 & Montenegro & 64 & 0.37 \\
\hline Chile & 227 & 1.30 & Netherlands & 187 & 1.07 \\
\hline Chinese-Taipei (Taiwan) & 214 & 1.22 & New Zealand & 183 & 1.05 \\
\hline Colombia & 372 & 2.13 & Norway & 229 & 1.31 \\
\hline Costa Rica & 205 & 1.17 & Peru & 281 & 1.61 \\
\hline Croatia & 160 & 0.92 & Poland & 169 & 0.97 \\
\hline Czech Republic & 344 & 1.97 & Portugal & 246 & 1.41 \\
\hline Denmark & 333 & 1.91 & Qatar & 167 & 0.96 \\
\hline Dominican Republic & 194 & 1.11 & Romania & 182 & 1.04 \\
\hline Estonia & 206 & 1.18 & Russian Federation & 210 & 1.20 \\
\hline Finland & 168 & 0.96 & Singapore & 177 & 1.01 \\
\hline France & 252 & 1.44 & Slovakia & 290 & 1.66 \\
\hline Georgia & 262 & 1.50 & Vietnam & 188 & 1.08 \\
\hline Germany & 256 & 1.46 & Slovenia & 333 & 1.91 \\
\hline Greece & 211 & 1.21 & Spain & 201 & 1.15 \\
\hline China (Hong Kong) & 138 & 0.79 & Sweden & 202 & 1.16 \\
\hline Hungary & 245 & 1.40 & Switzerland & 227 & 1.30 \\
\hline Iceland & 124 & 0.71 & Thailand & 273 & 1.56 \\
\hline Indonesia & 236 & 1.35 & Trinidad and Tobago & 149 & 0.85 \\
\hline Republic of Ireland & 167 & 0.96 & United Arab Emirates & 473 & 2.71 \\
\hline Israel & 173 & 0.99 & Turkey & 187 & 1.07 \\
\hline Italy & 474 & 2.71 & Macedonia & 106 & 0.61 \\
\hline Japan & 198 & 1.13 & United Kingdom & 550 & 3.15 \\
\hline Jordan & 250 & 1.43 & United States & 177 & 1.01 \\
\hline Korea & 168 & 0.96 & Uruguay & 220 & 1.26 \\
\hline Kosovo & 224 & 1.28 & Spain (Regions) & 976 & 5.59 \\
\hline Lebanon & 270 & 1.55 & Argentina (Buenos Aires) & 58 & 0.33 \\
\hline
\end{tabular}

Source: Obtained from primary data.

\subsection{Data Collection Tools}

The data for the schools taken as the study sample were utilized by utilizing the PISA 2015 database. These data were scaled in ready form. Within this scope, the means of these scales were used as inputs, while the countries' PISA 2015 Science success scores were used as outputs. These inputs and the questions with which they were obtained are presented in Table 2. 
Table-2. The inputs and its questions.

\begin{tabular}{|c|c|c|c|}
\hline Inputs & The Name of Inputs & Questions of Inputs & Questions \\
\hline \multirow{5}{*}{ Input 1} & \multirow{5}{*}{$\begin{array}{l}\text { Student behaviour hindering } \\
\text { learning (WLE) }\end{array}$} & SC061Q01TA & Student truancy \\
\hline & & SC061Q02TA & Students skipping classes \\
\hline & & SC061Q03TA & Students lacking respect for teachers \\
\hline & & SC061Q04TA & Student use of alcohol or illegal drugs \\
\hline & & SC061Q05TA & Students intimidating or bullying other students \\
\hline \multirow{5}{*}{ Input2 } & \multirow{5}{*}{$\begin{array}{l}\text { Teacher behaviour hindering } \\
\text { learning (WLE) }\end{array}$} & SC061Q06TA & Teachers not meeting individual students' needs \\
\hline & & SC061Q07TA & Teacher absenteeism \\
\hline & & SC061Q08TA & Staff resisting change \\
\hline & & SC061Q09TA & Teachers being too strict with students \\
\hline & & SC061Q010TA & Teachers not being well prepared for classes \\
\hline \multirow{4}{*}{ Input3 } & \multirow{4}{*}{$\begin{array}{l}\text { Shortage of educational } \\
\text { material (WLE) }\end{array}$} & SC017Q05NA & $\begin{array}{l}\text { A lack of educational material (e.g. textbooks, IT equipment, } \\
\text { library or laboratory material). }\end{array}$ \\
\hline & & SC017Q06NA & $\begin{array}{l}\text { Inadequate or poor quality educational material (e.g. } \\
\text { textbooks, IT equipment, library or laboratory material). }\end{array}$ \\
\hline & & SC0 17Q07NA & $\begin{array}{l}\text { A lack of physical infrastructure (e.g. building, grounds, } \\
\text { heating/cooling, lighting and acoustic systems). }\end{array}$ \\
\hline & & SC017Q08NA & $\begin{array}{l}\text { Inadequate or poor quality physical infrastructure (e.g. } \\
\text { building, grounds, heating/cooling, lighting and acoustic } \\
\text { systems) }\end{array}$ \\
\hline \multirow{4}{*}{ Input4 } & \multirow{4}{*}{$\begin{array}{l}\text { Shortage of educational staff } \\
\text { (WLE) }\end{array}$} & SCO17Q01NA & A lack of teaching staff \\
\hline & & SCO17Q02NA & Inadequate or poorly qualified teaching staff \\
\hline & & SCO17Q03NA & A lack of assisting staff. \\
\hline & & SCO17Q04NA & Inadequate or poorly qualified assisting staff \\
\hline \multirow{4}{*}{ Input5 } & \multirow{4}{*}{$\begin{array}{l}\text { Professional development } \\
\text { (WLE) }\end{array}$} & SC009Q06TA & $\begin{array}{l}\text { When a teacher has problems in his/her classroom, I take the } \\
\text { initiative to discuss matters. }\end{array}$ \\
\hline & & SCo09Q08TA & I pay attention to disruptive behaviour in classrooms \\
\hline & & SCoo9Q12TA & $\begin{array}{l}\text { When a teacher brings up a classroom problem, we solve the } \\
\text { problem together. }\end{array}$ \\
\hline & & SC009Q06TA & $\begin{array}{l}\text { When a teacher has problems in his/her classroom, I take the } \\
\text { initiative to discuss matters. }\end{array}$ \\
\hline \multirow{3}{*}{ Input6 } & \multirow{3}{*}{ Teachers participation (WLE) } & SCo09Q09TA & $\begin{array}{l}\text { I provide staff with opportunities to participate in school } \\
\text { decision-making }\end{array}$ \\
\hline & & SCO09Q010TA & $\begin{array}{l}\text { I engage teachers to help build a school culture of continuous } \\
\text { improvement }\end{array}$ \\
\hline & & SCo09Q011TA & $\begin{array}{l}\text { I ask teachers to participate in reviewing management } \\
\text { practices. }\end{array}$ \\
\hline \multirow{3}{*}{ Input7 } & \multirow{3}{*}{ Curricular development (WLE) } & SC009Q01TA & $\begin{array}{l}\text { I use student performance results to develop the school's } \\
\text { educational goals. }\end{array}$ \\
\hline & & SCo09Q02TA & $\begin{array}{l}\text { I make sure that the professional development activities of } \\
\text { teachers are in accordance with the teaching goals of the } \\
\text { school. }\end{array}$ \\
\hline & & SCoo9Q03TA & $\begin{array}{l}\text { I ensure that teachers work according to the school's } \\
\text { educational goals }\end{array}$ \\
\hline Input8 & $\begin{array}{l}\text { Total number of science } \\
\text { teachers at school }\end{array}$ & & \\
\hline \multirow{8}{*}{ Input9 } & \multirow{8}{*}{$\begin{array}{c}\text { Index science specific resources } \\
\text { (Sum) }\end{array}$} & SC059Q01NA & $\begin{array}{l}\text { Compared to other departments, our school's science } \\
\text { department is well equipped. }\end{array}$ \\
\hline & & SC059Q02NA & $\begin{array}{l}\text { If we ever have some extra funding, a big share goes into } \\
\text { improvement of our science teaching. }\end{array}$ \\
\hline & & SC059O03NA & Science teachers are among our best educated staff members. \\
\hline & & SC059Q04NA & $\begin{array}{l}\text { Compared to similar schools, we have a well-equipped } \\
\text { laboratory. }\end{array}$ \\
\hline & & SC059Q05NA & $\begin{array}{l}\text { The material for hands-on activities in science is in good } \\
\text { shape. }\end{array}$ \\
\hline & & SC059Q06NA & $\begin{array}{l}\text { We have enough laboratory material that all courses can } \\
\text { regularly use. }\end{array}$ \\
\hline & & SC059Q07NA & $\begin{array}{l}\text { We have extra laboratory staff who help support science } \\
\text { teaching. }\end{array}$ \\
\hline & & SC059Q08NA & $\begin{array}{l}\text { Our school spends extra money on up-to-date science } \\
\text { equipment. }\end{array}$ \\
\hline
\end{tabular}

Source: Obtained from primary data.

\subsection{Data Analysis}

The aim of this study was to investigate whether or not the inputs or efforts considered to affect the PISA 2015 Science success scores were used efficiently by the countries. With this aim, to determine the relative efficiency, data envelopment analysis was used. The analysis was performed in line with the views of Lorcu (2008):

1. Firstly, the Decision Making Units (DMU) were determined. According to Dyson et al. (2001)) form inputs and $\mathrm{s}$ outputs, the number of decision making units should be $2 \mathrm{mXs}$. In this study, 70 countries (68 were taken for analysis; the reason for this is presented below) were sufficient as DMUs for the 9 inputs and 1 output.

2. According to Cooper et al. (2001) form inputs and s outputs, there should be an $\mathbf{N}$ number of DMUs, where $\mathrm{N} \geq\{\mathrm{m} \times \mathrm{s} ; 3 \mathrm{X}(\mathrm{m}+\mathrm{s})$. Accordingly, since $70(68) \geq\{9 \times 1 ; 3 \mathrm{X}(9+1)\}=70(68) \geq\{9 ; 30\}$, the number of DMUs was sufficient.

3. $\mathrm{z}$ distribution should be controlled. In the first $\mathrm{z}$ distribution in the study, since there were outliers in the input scores for Tunisia and China (Beijing-Shanghai-Jiangsu-Guangdong), these were removed. It was seen that there were no outliers in the $\mathrm{z}$ scores recalculated for the remaining 68 countries. Both $\mathrm{z}$ distributions are shown in Table 3. To facilitate interpretation of the scores and to remove negative values, conversion to $\mathrm{T}$ scores was performed. 
Table-3. Distribution of inputs for 68 countries.

\begin{tabular}{l|c|c|c|c|c|c}
\hline Inputs & N & Minimum & Maximum & N & Minimum & Maximum \\
\hline Student behaviour hindering learning (WLE) & 70 & $-1,87272$ & 2,06593 & 68 & $-1,85571$ & 2,05420 \\
\hline Teacher behaviour hindering learning (WLE) & 70 & $-2,07622$ & 2,43954 & 68 & $-2,07918$ & 2,52854 \\
\hline Shortage of educational material (WLE) & 70 & $-1,96928$ & 2,12009 & 68 & $-1,96773$ & 2,21297 \\
\hline Shortage of educational staff(WLE) & 70 & $-2,12386$ & 3,58366 & 68 & $-2,26788$ & 2,37804 \\
\hline Professional development (WLE) & 70 & $-2,35916$ & 2,90058 & 68 & $-2,47614$ & 2,14454 \\
\hline Teachers participation (WLE) & 70 & $-2,09584$ & 2,42160 & 68 & $-2,06065$ & 2,40872 \\
\hline Curricular development (WLE) & 70 & $-2,30067$ & 2,18401 & 68 & $-2,45245$ & 2,21827 \\
\hline Total number of science teachers at school & 70 & $-2,95748$ & 1,84587 & 68 & $-3,08392$ & 1,85672 \\
\hline Index science specific resources (Sum) & 70 & $-1,13323$ & 5,53576 & 68 & $-1,43348$ & 2,86126 \\
\hline Source: Obtained from primary dat & & & &
\end{tabular}

4. Correlation control was performed for the 68 countries. No high correlation was determined. The correlation results are presented in Table 4 .

Table-4. Correlations between inputs.

\begin{tabular}{|c|c|c|c|c|c|c|c|c|c|c|}
\hline No & Inputs & $\begin{array}{c}\text { Input } \\
2\end{array}$ & $\begin{array}{c}\text { Input } \\
3\end{array}$ & $\begin{array}{c}\text { Input } \\
4\end{array}$ & $\begin{array}{c}\text { Input } \\
5\end{array}$ & $\begin{array}{c}\text { Input } \\
6\end{array}$ & $\begin{array}{c}\text { Input } \\
7\end{array}$ & $\begin{array}{c}\text { Input } \\
8\end{array}$ & $\begin{array}{c}\text { Input } \\
9\end{array}$ & $\begin{array}{l}\text { PISA } \\
\text { Score }\end{array}$ \\
\hline Input 1 & $\begin{array}{l}\text { Student behaviour hindering learning } \\
\text { (WLE) }\end{array}$ &,- 107 &, 171 &,$- 43^{* *}$ &,- 038 &,- 013 &,- 113 &, 104 &, $415^{* *}$ &, $331^{* *}$ \\
\hline Input2 & $\begin{array}{l}\text { Teacher behaviour hindering learning } \\
\text { (WLE) }\end{array}$ & &, $475^{* *}$ &, 163 &, 227 & ,011 & ,079 &,- 021 &,- 190 & ,086 \\
\hline Input3 & Shortage of educational material (WLE) & & & ,058 &, $495^{* *}$ &,- 099 &,- 154 &,- 107 & ,025 &, 187 \\
\hline Input4 & Shortage of educational staff (WLE) & & & &, $534^{* *}$ &, 168 &, 120 &,- 004 &,- 189 &,$- 403^{* *}$ \\
\hline Input5 & Professional development (WLE) & & & & &,- 058 &,- 067 &,- 201 & ,032 &, 004 \\
\hline Input6 & Teachers participation (WLE) & & & & & & ,633** & ,654*** & ,033 &,$- 592^{* *}$ \\
\hline Input7 & Curricular development (WLE) & & & & & & &, $671^{* *}$ &,- 224 &,$- 491^{* *}$ \\
\hline Input8 & Total number of science teachers at school & & & & & & & & ,038 &,$- 481^{* *}$ \\
\hline Input9 & Index science specific resources (Sum) & & & & & & & & & ,268* \\
\hline
\end{tabular}

5. Starting with the hypothesis that as decision-makers, we would have an effect on the inputs, analysis of the inputs was made. Moreover, under the hypotheses of constant returns and returns to scale used in approaches of this type, an attempt was made to obtain the countries' total, technical and scale efficiency values. Total efficiency was calculated with the input-based CCR model developed by Charnes et al. (1978) while technical efficiency was calculated with Banker et al. (1984) BCC model and scale efficiency was calculated with the ratio of these. Furthermore, returns to scale situations were also calculated.

\section{Findings}

In the study, the research results for total efficiency calculated with the CCR model, technical efficiency with the BCC model, scale efficiency with the $\mathrm{CCR} / \mathrm{BCC}$ ratio, and returns to scale with total lambdas of the selected countries are presented in Table 5. According to the analyses made, a total of 15 countries/regions (Canada, Switzerland, Estonia, Finland, Hong Kong (China), Hungary, Iceland, Japan, Korea, Lithuania, Macao (China), Poland, Singapore, Slovenia and Vietnam) out of the 68 countries/regions were totally efficient. Of the countries that were totally efficient, the top three countries shown as references were Japan (37), Poland (35) and Estonia (34). Vietnam, which was a totally efficient country, was not shown as a reference for any other country. On the other hand, the totally efficient Slovenia was shown as a reference for Latvia and Sweden. Latvia's reference coefficient was extremely low, and, due to rounding down, was evaluated as zero.

When the general distribution of totally efficient countries is examined, it is seen that they mostly consist of continental European and Asia-Pacific countries. 12 of the countries (which countries) that were above the OECD average in the PISA 2015 science scores listing were also totally efficient. It was determined that the five countries that were closest to total efficiency (Taiwan (China), the Netherlands, Austria, Denmark and France) were also among the countries above the OECD average.

The analysis revealed that 53 countries were inefficient. The five countries furthest from total efficiency were Jordan, Kosovo, Trinidad and Tobago, Algeria and the Dominican Republic. Again, it is seen that these countries occupied the last places in the PISA 2015 science success listing, and that in fact, the Dominican Republic was in last place for both total efficiency and academic success. In other words, these countries' efforts were not sufficient.

Examining the countries' returns to scale situations, it is seen that apart from New Zealand, all countries had increasing returns to scale. That is to say, an input of 1 unit in their inputs resulted in an output greater than 1 in their outputs. Examining the recommendations made for countries that were not totally efficient in order for them to become efficient, it was determined that there was no reference indicator in regional terms. In most reference indicators, there was a mixture of Europe and Asia-Pacific. It was determined that especially Canada and totally efficient countries in Europe were mostly references for their neighbours.

Turkey was one of the countries that were not totally efficient. Turkey's total efficiency ratio was $71.92 \%$. With this score, Turkey was in 51 st place in the list of 68 countries. Estonia and Japan were references for Turkey. That is, for Turkey to be totally efficient, it needed to use its inputs with the input ratios of those countries. 


\begin{tabular}{|c|c|c|c|c|c|c|c|c|c|c|c|c|c|c|c|c|}
\hline NO & DMU & CCR & Country 1 & $\lambda 1$ & Country 2 & $\lambda 2$ & Country 3 & $\lambda 3$ & Country4 & $\lambda 4$ & Country 5 & $\lambda 5$ & Country 6 & $\lambda 6$ & Total $\lambda$ & Returns to Scale \\
\hline 1 & Albania & 0,8635 & Hungary & 0,37 & Japan & 0,08 & Korea & 0,08 & \begin{tabular}{|l} 
Singapore \\
\end{tabular} & 0,19 & & & & & 0,72 & Increasing \\
\hline 2 & United Arab Emirates & 0,7140 & Japan & 0,15 & Korea & 0,12 & Singapore & 0,4 & & & & & & & 0,67 & Increasing \\
\hline 3 & Australia & 0,9040 & Canada & 0,24 & Estonia & 0,24 & Iceland & 0,01 & Poland & 0,12 & Singapore & 0,31 & & & 0,92 & Increasing \\
\hline 4 & Austria & 0,9666 & Switzerland & 0,21 & Estonia & 0,29 & Finland & 0,32 & Japan & 0,01 & Singapore & 0,07 & & & 0,9 & Increasing \\
\hline 5 & Belgium & 0,8640 & Switzerland & 0,16 & Japan & 0,2 & China (Macao) & 0,11 & Poland & 0,49 & & & & & 0,96 & Increasing \\
\hline 6 & Bulgaria & 0,8621 & Japan & 0,04 & Poland & 0,76 & & & & & & & & & 0,8 & Increasing \\
\hline 7 & Brazil & 0,6502 & Estonia & 0,03 & Finland & 0,21 & Japan & 0,3 & Poland & 0,04 & & & & & 0,58 & Increasing \\
\hline 8 & Canada & 1,0000 & Canada & 1 & & & & & & & & & & & 1 & \\
\hline 9 & Switzerland & 1,0000 & Switzerland & 1 & & & & & & & & & & & 1 & \\
\hline 10 & Chile & 0,8566 & Canada & 0,11 & Iceland & 0,59 & Poland & 0,08 & Singapore & 0,06 & & & & & 0,84 & Increasing \\
\hline 11 & Colombia & 0,5974 & Estonia & 0,59 & Japan & 0,03 & & & & & & & & & 0,62 & Increasing \\
\hline 12 & Costa Rica & 0,6396 & Estonia & 0,46 & Japan & 0,17 & & & & & & & & & 0,63 & Increasing \\
\hline 13 & Czech Republic & 0,9004 & Estonia & 0,34 & Finland & 0,16 & Japan & 0,02 & Poland & 0,39 & & & & & 0,91 & Increasing \\
\hline 14 & Germany & 0,8775 & Switzerland & 0,15 & Estonia & 0,17 & Finland & 0,38 & Japan & 0,1 & Singapore & 0,13 & & & 0,93 & Increasing \\
\hline 15 & Denmark & 0,9596 & Switzerland & 0,14 & Estonia & 0,26 & Finland & 0,01 & Japan & 0,02 & Poland & 0,5 & Singapore & 0,04 & 0,97 & Increasing \\
\hline 16 & Dominican Republic & 0,3872 & Estonia & 0,27 & Japan & 0,04 & Poland & 0,05 & & & & & & & 0,36 & Increasing \\
\hline 17 & Algeria & 0,5164 & Estonia & 0,49 & & & & & & & & & & & 0,49 & Increasing \\
\hline 18 & Spain & 0,8661 & Estonia & 0,18 & Hungary & 0,1 & Japan & 0,18 & Korea & 0,14 & Poland & 0,19 & Singapore & 0,12 & 0,91 & Increasing \\
\hline 19 & Estonia & 1,0000 & Estonia & 1 & & & & & & & & & & & 1 & \\
\hline 20 & Finland & 1,0000 & Finland & 1 & & & & & & & & & & & 1 & \\
\hline 21 & France & 0,9446 & Switzerland & 0,56 & Japan & 0,01 & China (Macao) & 0,36 & & & & & & & 0,93 & Increasing \\
\hline 22 & United Kingdom & 0,9280 & China (Hong Kong) & 0,46 & Japan & 0,03 & Korea & 0,17 & Poland & 0,21 & Singapore & 0,08 & & & 0,95 & Increasing \\
\hline 23 & Georgia & 0,7821 & Estonia & 0,04 & Hungary & 0,18 & Korea & 0,33 & Lithuania & 0,03 & Poland & 0,08 & & & 0,66 & Increasing \\
\hline 24 & Greece & 0,8704 & Estonia & 0,16 & Japan & 0,03 & Korea & 0,59 & & & & & & & 0,78 & Increasing \\
\hline 25 & China (Hong Kong) & 1,0000 & China (Hong Kong) & 1 & & & & & & & & & & & 1 & \\
\hline 26 & Croatia & 0,7852 & Japan & 0,49 & Poland & 0,35 & & & & & & & & & 0,84 & Increasing \\
\hline 27 & Hungary & 1,0000 & Hungary & 1 & & & & & & & & & & & 1 & Increasing \\
\hline 28 & Indonesia & 0,8515 & Hungary & 0,05 & Korea & 0,35 & Singapore & 0,21 & & & & & & & 0,61 & Increasing \\
\hline 29 & Republic of Ireland & 0,8509 & Estonia & 0,63 & Japan & 0,13 & Poland & 0,14 & & & & & & & 0,9 & Increasing \\
\hline 30 & Iceland & 1,0000 & Iceland & 1 & & & & & & & & & & & 1 & \\
\hline 31 & Israel & 0,7019 & Estonia & 0,39 & China (Hong Kong) & 0,08 & Japan & 0,19 & Korea & 0,01 & Poland & 0,11 & & & 0,78 & Increasing \\
\hline 32 & Italy & 0,7210 & Estonia & 0,17 & Finland & 0,08 & Japan & 0,28 & Poland & 0,07 & Singapore & 0,21 & & & 0,81 & Increasing \\
\hline 33 & Jordan & 0,5733 & Estonia & 0,58 & Japan & 0,01 & & & & & & & & & 0,59 & Increasing \\
\hline 34 & Japan & 1,0000 & Japan & 1 & & & & & & & & & & & 1 & \\
\hline 35 & Korea & 1,0000 & Korea & 1 & & & & & & & & & & & 1 & \\
\hline 36 & Kosovo & 0,5411 & Japan & 0,37 & Poland & 0,15 & & & & & & & & & 0,52 & Increasing \\
\hline 37 & Lebanon & 0,5872 & Japan & 0,13 & Korea & 0,09 & Singapore & 0,29 & & & & & & & 0,51 & Increasing \\
\hline 38 & Lithuania & 1,0000 & Lithuania & 1 & & & & & & & & & & & 1 & \\
\hline 39 & Luxembourg & 0,9271 & Switzerland & 0,44 & Japan & 0,17 & China (Macao) & 0,27 & & & & & & & 0,88 & Increasing \\
\hline 40 & Latvia & 0,9270 & Estonia & 0,32 & Poland & 0,6 & Slovenia & 0 & & & & & & & 0,92 & Increasing \\
\hline
\end{tabular}


Asian Journal of Education and Training, 2019, 5(2): 349-361

\begin{tabular}{|c|c|c|c|c|c|c|c|c|c|c|c|c|c|c|}
\hline 41 & China (Macao) & 1,0000 & China (Macao) & & & & & & & & & & 1 & \\
\hline 42 & Moldova & 0,6850 & Estonia & 0,46 & Poland & 0,23 & & & & & & & 0,69 & Increasing \\
\hline 43 & Mexico & 0,6251 & Estonia & 0,09 & Japan & 0,39 & Poland & 0,15 & & & & & 0,63 & Increasing \\
\hline 44 & Macedonia & 0,6588 & Estonia & 0,04 & Hungary & 0,13 & Poland & 0,41 & & & & & 0,58 & Increasing \\
\hline 45 & Malta & 0,8411 & China (Hong Kong) & 0,63 & Korea & 0,15 & Poland & 0,01 & Singapore & 0,02 & & & 0,81 & Increasing \\
\hline 46 & Montenegro & 0,7586 & Japan & 0,22 & Poland & 0,43 & & & & & & & 0,65 & Increasing \\
\hline 47 & Netherlands & 0,9765 & Switzerland & 0,28 & Estonia & 0,25 & China (Hong Kong) & 0,41 & Japan & 0,03 & & & 0,97 & Increasing \\
\hline 48 & Norway & 0,8980 & Estonia & 0,27 & Finland & 0,24 & Japan & 0,15 & \begin{tabular}{|l|} 
Poland \\
\end{tabular} & 0,09 & Singapore & 0,13 & 0,88 & Increasing \\
\hline 49 & New Zealand & 0,8794 & Estonia & 0,05 & China (Hong Kong) & 0,29 & Poland & 0,66 & Singapore & 0,02 & & & 1,02 & Decreasing \\
\hline 50 & Peru & 0,5846 & Estonia & 0,16 & Japan & 0,4 & & & & & & & 0,56 & Increasing \\
\hline 51 & Poland & 1,0000 & Poland & 1 & & & & & & & & & 1 & \\
\hline 52 & Portugal & 0,7663 & Switzerland & 0,14 & Estonia & 0,31 & Japan & 0,09 & Poland & 0,3 & Singapore & 0,1 & 0,94 & Increasing \\
\hline 53 & Argentina (Buenos Aires) & 0,6985 & Estonia & 0,08 & Japan & 0,15 & Poland & 0,22 & Singapore & 0,36 & & & 0,81 & Increasing \\
\hline 54 & Qatar & 0,8148 & Korea & 0,22 & Poland & 0,02 & Singapore & 0,37 & & & & & 0,61 & Increasing \\
\hline 55 & Spain (Regions) & 0,8800 & Hungary & 0,19 & Japan & 0,19 & Korea & 0,04 & Poland & 0,41 & Singapore & 0,11 & 0,94 & Increasing \\
\hline 56 & Romania & 0,8624 & Lithuania & 0,57 & Poland & 0,24 & & & & & & & 0,81 & Increasing \\
\hline 57 & Russian Federation & 0,7899 & Estonia & 0,411 & Japan & 0,29 & Poland & 0,16 & & & & & 0,86 & Increasing \\
\hline 58 & Singapore & 1,0000 & Singapore & & & & & & & & & & 0 & \\
\hline 59 & Slovakia & 0,8867 & Estonia & 0,18 & Hungary & 0,16 & Poland & 0,51 & & & & & 0,85 & Increasing \\
\hline 60 & Slovenia & 1,0000 & Slovenia & & & & & & & & & & 0 & \\
\hline 61 & Sweden & 0,9194 & Canada & 0,06 & Estonia & 0,53 & Singapore & 0,2 & Slovenia & 0,06 & & & 0,85 & Increasing \\
\hline 62 & Chinese-Taipei (Taiwan) & 0,9959 & Japan & 0,33 & Singapore & 0,62 & & & & & & & 0,95 & Increasing \\
\hline 63 & Thailand & 0,7457 & Hungary & 0,25 & Korea & 0,23 & Lithuania & 0,12 & Poland & 0,13 & & & 0,73 & Increasing \\
\hline 64 & Trinidad and Tobago & 0,5390 & Estonia & 0,57 & Japan & 0,05 & Poland & 0,04 & & & & & 0,66 & Increasing \\
\hline 65 & Turkey & 0,7192 & Estonia & 0,21 & Japan & 0,44 & & & & & & & 0,65 & Increasing \\
\hline 66 & Uruguay & 0,6042 & Estonia & 0,46 & China (Hong Kong) & 0,18 & Japan & 0,04 & Poland & 0,01 & & & 0,69 & Increasing \\
\hline 67 & United States & 0,8614 & Canada & 0,23 & Estonia & 0,25 & Poland & 0,15 & Singapore & 0,26 & & & 0,89 & Increasing \\
\hline 68 & Vietnam & 1,0000 & Vietnam & 1 & & & & & & & & & & \\
\hline
\end{tabular}


Table-6. Total, Technical and Scale Efficiencies of Countries and their Returns to Scale

\begin{tabular}{|c|c|c|c|c|c|}
\hline NO & Countries & CCR & BCC & Scale Efficient & Returns to Scale \\
\hline 8 & Canada & 1 & 1 & 1 & \\
\hline 9 & Switzerland & 1 & 1 & 1 & \\
\hline 19 & Estonia & 1 & 1 & 1 & \\
\hline 20 & Finland & 1 & 1 & 1 & \\
\hline 25 & China (Hong Kong) & 1 & 1 & 1 & \\
\hline 27 & Hungary & 1 & 1 & 1 & \\
\hline 30 & Iceland & 1 & 1 & 1 & \\
\hline 34 & Japan & 1 & 1 & 1 & \\
\hline 35 & Korea & 1 & 1 & 1 & \\
\hline 38 & Lithuania & 1 & 1 & 1 & \\
\hline 41 & China (Macao) & 1 & 1 & 1 & \\
\hline 51 & Poland & 1 & 1 & 1 & \\
\hline 58 & Singapore & 1 & 1 & 1 & \\
\hline 60 & Slovenia & 1 & 1 & 1 & \\
\hline 68 & Vietnam & 1 & 1 & 1 & \\
\hline 62 & Chinese-Taipei (Taiwan) & 0,9959 & 1 & 0,9959 & Increasing \\
\hline 47 & Netherlands & 0,9765 & 1 & 0,9765 & Increasing \\
\hline 4 & Austria & 0,9666 & 1 & 0,9666 & Increasing \\
\hline 21 & France & 0,9446 & 1 & 0,9446 & Increasing \\
\hline 39 & Luxembourg & 0,9271 & 1 & 0,9271 & Increasing \\
\hline 1 & Albania & 0,8635 & 1 & 0,8635 & Increasing \\
\hline 56 & Romania & 0,8624 & 1 & 0,8624 & Increasing \\
\hline 6 & Bulgaria & 0,8621 & 1 & 0,8621 & Increasing \\
\hline 10 & Chile & 0,8566 & 1 & 0,8566 & Increasing \\
\hline 28 & Indonesia & 0,8515 & 1 & 0,8515 & Increasing \\
\hline 54 & Qatar & 0,8148 & 1 & 0,8148 & Increasing \\
\hline 23 & Georgia & 0,7821 & 1 & 0,7821 & Increasing \\
\hline 46 & Montenegro & 0,7586 & 1 & 0,7586 & Increasing \\
\hline 65 & Turkey & 0,7192 & 1 & 0,7192 & Increasing \\
\hline 44 & Macedonia & 0,6588 & 1 & 0,6588 & Increasing \\
\hline 7 & Brazil & 0,6502 & 1 & 0,6502 & Increasing \\
\hline 37 & Lebanon & 0,5872 & 1 & 0,5872 & Increasing \\
\hline 50 & Peru & 0,5846 & 1 & 0,5846 & Increasing \\
\hline 59 & Slovakia & 0,8867 & 0,9954 & 0,8908 & Increasing \\
\hline 24 & Greece & 0,8704 & 0,9886 & 0,8804 & Increasing \\
\hline 36 & Kosovo & 0,5411 & 0,981 & 0,5516 & Increasing \\
\hline 40 & Latvia & 0,927 & 0,9802 & 0,9457 & Increasing \\
\hline 17 & Algeria & 0,5164 & 0,9794 & 0,5273 & Increasing \\
\hline 45 & Malta & 0,8411 & 0,9777 & 0,8603 & Increasing \\
\hline 16 & Dominican Republic & 0,3872 & 0,9688 & 0,3997 & Increasing \\
\hline 15 & Denmark & 0,9596 & 0,9641 & 0,9953 & Increasing \\
\hline 61 & Sweden & 0,9194 & 0,9535 & 0,9642 & Increasing \\
\hline 63 & Thailand & 0,7457 & 0,9519 & 0,7834 & Increasing \\
\hline 13 & Czech Republic & 0,9004 & 0,9421 & 0,9557 & Increasing \\
\hline 22 & United Kingdom & 0,928 & 0,9387 & 0,9886 & Increasing \\
\hline 42 & Moldova & 0,685 & 0,9342 & 0,7332 & Increasing \\
\hline 12 & Costa Rica & 0,6396 & 0,9255 & 0,6911 & Increasing \\
\hline 48 & Norway & 0,898 & 0,9219 & 0,9741 & Increasing \\
\hline 43 & Mexico & 0,6251 & 0,919 & 0,6802 & Increasing \\
\hline 3 & Australia & 0,904 & 0,9182 & 0,9845 & Increasing \\
\hline 55 & Spain (Regions) & 0,88 & 0,9134 & 0,9634 & Increasing \\
\hline 2 & United Arab Emirates & 0,714 & 0,9107 & 0,784 & Increasing \\
\hline 18 & Spain & 0,8661 & 0,9022 & 0,96 & Increasing \\
\hline 67 & United States & 0,8614 & 0,8986 & 0,9586 & Increasing \\
\hline 5 & Belgium & 0,864 & 0,8977 & 0,9625 & Increasing \\
\hline 11 & Colombia & 0,5974 & 0,8942 & 0,6681 & Increasing \\
\hline 29 & Republic of Ireland & 0,8509 & 0,8933 & 0,9525 & Increasing \\
\hline 14 & Germany & 0,8775 & 0,8901 & 0,9858 & Increasing \\
\hline 26 & Croatia & 0,7852 & 0,8828 & 0,8894 & Increasing \\
\hline 49 & New Zealand & 0,8794 & 0,8796 & 0,9998 & Decreasing \\
\hline 57 & Russian Federation & 0,7899 & 0,8772 & 0,9005 & Increasing \\
\hline 33 & Jordan & 0,5733 & 0,8626 & 0,6646 & Increasing \\
\hline 31 & Israel & 0,7019 & 0,8317 & 0,8439 & Increasing \\
\hline 53 & Argentina (Buenos Aires) & 0,6985 & 0,8303 & 0,8413 & Increasing \\
\hline 32 & Italy & 0,721 & 0,8065 & 0,894 & Increasing \\
\hline 52 & Portugal & 0,7663 & 0,7824 & 0,9794 & Increasing \\
\hline 64 & Trinidad and Tobago & 0,539 & 0,7692 & 0,7007 & Increasing \\
\hline 66 & Uruguay & 0,6042 & 0,7688 & 0,7859 & Increasing \\
\hline
\end{tabular}

Source: Obtained from primary data.

As shown the Table 6, when technical efficiency was evaluated, it was determined that 33 countries were technically efficient, while 35 countries were not technically efficient. This proportion is almost fifty fifty. 18 of the countries (Taiwan (China), the Netherlands, Austria, France, Luxembourg, Albania, Romania, Bulgaria, Chile, Indonesia, 
Qatar, Georgia, Montenegro, Turkey, Macedonia, Brazil, Lebanon and Peru) that were not totally efficient appeared as technically efficient.

Another type of efficiency examined in the study was that of scale efficiency. The results of the analysis reveal that only 15 of the totally efficient countries (Canada, Switzerland, Estonia, Finland, Hong Kong (China), Hungary, Iceland, Japan, Korea, Lithuania, Macao (China), Poland, Singapore, Slovenia and Vietnam) appeared as scale efficient. None of the 18 countries that were technically efficient (Taiwan (China), the Netherlands, Austria, France, Luxembourg, Albania, Romania, Bulgaria, Chile, Indonesia, Qatar, Georgia, Montenegro, Turkey, Macedonia, Brazil, Lebanon and Peru) appeared as scale efficient. A total of 35 countries (Slovakia, Greece, Kosovo, Latvia, Algeria, Malta, the Dominican Republic, Denmark, Sweden, Thailand, the Czech Republic, Great Britain, Moldova, Costa Rica, Norway, Mexico, Australia, Spain (Regions), the United Arab Emirates, Spain, the United States, Belgium, Colombia, the Republic of Ireland, Germany, Croatia, New Zealand, Russia, Jordan, Israel, Buenos Aires (Argentina), Italy, Portugal, Trinidad and Tobago and Uruguay) were neither technically nor scale efficient. These countries could not produce on a suitable scale and used their resources incorrectly, leading to waste (Lorcu, 2008).

The analysis results revealed that Turkey was not scale efficient. With a ratio of $71.92 \%$, Turkey was in 56 th place in the list of countries. The countries below Turkey were Middle Eastern (Jordan, Lebanon and Algeria), Balkan (Kosovo and Macedonia), and especially Latin American (Trinidad and Tobago, Costa Rica, Mexico, Colombia, Brazil, Peru and the Dominican Republic) countries. Turkey and the other countries need to reorganize their inputs in order to become totally efficient. This situation is expressed as hypothetical input. For these inputs, the percentage reduction rates for the inputs of these countries are presented in Table 7.

Table-7. Percentage reduction rates for countries' hypothetical inputs.

\begin{tabular}{|c|c|c|c|c|c|c|c|c|c|c|}
\hline NO & DMU & Input 1 & Inpute & Input3 & Input4 & Input5 & Input6 & Input7 & Input8 & Input9 \\
\hline 62 & $\begin{array}{c}\text { Chinese- } \\
\text { Taipei } \\
\text { (Taiwan) }\end{array}$ & 0,41 & 0,41 & 1,179666 & 13,7512 & 19,3463 & 6,1131 & 18,7791 & 18,1933 & 8,6619 \\
\hline 47 & Netherlands & 2,35 & 34,3886 & 31,68467 & 2,3500 & 11,9847 & 2,3500 & 4,1952 & 27,0037 & 2,3500 \\
\hline 4 & Australia & 3,34 & 17,21739 & 11,32106 & 3,3400 & 20,6639 & 3,3400 & 3,3400 & 3,3400 & 12,6728 \\
\hline 15 & Denmark & 4,04 & 4,04 & 18,85167 & 4,0400 & 4,0400 & 27,9978 & 27,6577 & 4,0400 & 4,0400 \\
\hline 21 & France & 5,54 & 16,34248 & 16,20656 & 5,5400 & 17,1621 & 31,7544 & 5,5400 & 28,0071 & 17,9762 \\
\hline 22 & $\begin{array}{c}\text { United } \\
\text { Kingdom }\end{array}$ & 7,2 & 7,2 & 7,2 & 9,7808 & 7,2000 & 37,2942 & 26,9896 & 41,0381 & 7,2000 \\
\hline 39 & Luxembourg & 31,120877 & 20,99233 & 7,29 & 7,2900 & 24,1121 & 38,5281 & 7,2900 & 36,5538 & 24,9321 \\
\hline 40 & Latvia & 23,622925 & 13,14401 & 7,3 & 7,3000 & 31,0314 & 24,0729 & 22,0382 & 23,2473 & 7,3000 \\
\hline 61 & Sweden & 8,06 & 21,56784 & 18,4718 & 8,0600 & 28,7500 & 8,0600 & 23,3917 & 11,0841 & 8,0600 \\
\hline 3 & Australia & 21,029468 & 9,6 & 23,64318 & 9,6000 & 9,6000 & 9,6000 & 25,6593 & 27,4727 & 9,6000 \\
\hline 13 & $\begin{array}{c}\text { Czech } \\
\text { Republic }\end{array}$ & 9,96 & 15,23478 & 9,96 & 9,9600 & 9,9600 & 17,4456 & 10,0054 & 23,8044 & 26,0640 \\
\hline 48 & Norway & 10,2 & 10,2 & 31,56588 & 10,2000 & 10,2000 & 16,0262 & 21,6251 & 32,7815 & 10,2000 \\
\hline 59 & Slovakia & 11,33 & 22,87238 & 11,33 & 21,5541 & 11,3300 & 33,7618 & 28,8305 & 43,0068 & 18,9558 \\
\hline 55 & $\begin{array}{c}\text { Spain } \\
\text { (Regions) }\end{array}$ & 12 & 12 & 12 & 12,0000 & 30,1987 & 26,7861 & 22,7905 & 12,0000 & 12,3412 \\
\hline 49 & New Zealand & 12,06 & 17,3037 & 22,60662 & 12,0600 & 22,2703 & 12,0600 & 24,7238 & 37,4955 & 12,0600 \\
\hline 14 & Germany & 12,25 & 12,79305 & 20,84747 & 12,2500 & 26,2408 & 12,2500 & 12,2500 & 12,2500 & 21,6741 \\
\hline 24 & Greece & 16,51095 & 12,96 & 12,96 & 23,4581 & 34,2359 & 30,0037 & 29,4406 & 25,6073 & 12,9600 \\
\hline 18 & Spain & 13,39 & 13,39 & 13,39 & 13,3900 & 23,4020 & 28,3511 & 18,7795 & 13,3900 & 13,3900 \\
\hline 5 & Belgium & 13,6 & 18,96346 & 28,59455 & 13,6000 & 32,0794 & 32,2257 & 13,6000 & 24,6390 & 13,6000 \\
\hline 1 & Albania & 13,65 & 13,65 & 13,65 & 43,8646 & 27,0993 & 56,0900 & 49,6056 & 44,2956 & 13,6500 \\
\hline 56 & Romania & 34,344399 & 24,94393 & 13,76 & 13,7600 & 28,3417 & 33,8643 & 44,5774 & 40,9121 & 46,3502 \\
\hline 6 & Bulgaria & 13,79 & 22,57853 & 23,63463 & 22,0770 & 13,7900 & 52,0827 & 48,0497 & 54,5018 & 21,8415 \\
\hline 67 & $\begin{array}{l}\text { United } \\
\text { States }\end{array}$ & 13,86 & 25,50405 & 20,2285 & 13,8600 & 13,8600 & 33,8979 & 34,4570 & 37,5156 & 13,8600 \\
\hline 10 & Chile & 24,697078 & 14,34 & 34,68483 & 14,3400 & 14,3400 & 14,8210 & 20,8200 & 34,3366 & 14,3400 \\
\hline 28 & Indonesia & 14,85 & 14,85 & 14,85 & 58,7276 & 37,2498 & 45,6712 & 48,2556 & 43,9182 & 18,5493 \\
\hline 29 & $\begin{array}{c}\text { Republic of } \\
\text { Ireland }\end{array}$ & 36,729693 & 14,91 & 22,19725 & 15,4192 & 14,9100 & 24,5992 & 29,7712 & 15,2819 & 14,9100 \\
\hline 45 & Malta & 25,562443 & 15,89 & 15,89 & 20,7528 & 15,8900 & 61,7133 & 36,0633 & 29,7510 & 15,8900 \\
\hline 54 & Qatar & 43,972102 & 18,52 & 18,52 & 30,2472 & 18,5200 & 52,2928 & 42,7348 & 52,7342 & 49,5123 \\
\hline 57 & $\begin{array}{c}\text { Russian } \\
\text { Federation }\end{array}$ & 37,134488 & 41,40629 & 26,24585 & 21,0100 & 21,2443 & 39,1383 & 21,0100 & 44,8810 & 21,0100 \\
\hline 26 & Croatia & 21,48 & 51,59208 & 30,13419 & 34,9890 & 21,4800 & 42,3832 & 50,2355 & 57,3564 & 29,1336 \\
\hline 23 & Georgia & 21,79 & 21,79 & 21,79 & 34,9955 & 21,7900 & 56,4775 & 51,4114 & 45,0387 & 21,7900 \\
\hline 52 & Portugal & 23,37 & 23,37 & 23,37 & 23,3700 & 43,9348 & 38,4243 & 33,0523 & 23,3700 & 41,5322 \\
\hline 46 & Montenegro & 24,14 & 46,49518 & 37,35317 & 43,5811 & 24,1400 & 63,1785 & 62,7513 & 68,1030 & 44,1156 \\
\hline 63 & Thailand & 25,43 & 25,43 & 25,43 & 25,4300 & 38,4761 & 35,5938 & 48,9402 & 40,7981 & 37,6314 \\
\hline 32 & Italy & 27,9 & 31,54264 & 29,13209 & 27,9000 & 27,9000 & 34,2268 & 27,9000 & 27,9000 & 38,3123 \\
\hline 65 & Turkey & 28,08 & 52,33819 & 34,74174 & 28,0800 & 41,4593 & 64,3816 & 69,6966 & 67,3763 & 37,6027 \\
\hline 2 & $\begin{array}{c}\text { United Arab } \\
\text { Emirates } \\
\end{array}$ & 46,31994 & 28,6 & 28,6 & 39,2833 & 42,5411 & 45,6664 & 47,7577 & 51,8846 & 28,6000 \\
\hline 31 & Israel & 39,215089 & 29,81 & 29,81 & 31,3629 & 29,8100 & 45,6293 & 29,8319 & 41,3017 & 29,8100 \\
\hline 53 & $\begin{array}{c}\text { Argentina } \\
\text { (Buenos } \\
\text { Aires) }\end{array}$ & 30,15 & 33,06685 & 31,08413 & 30,1500 & 30,1500 & 32,6883 & 30,1500 & 34,9841 & 31,0367 \\
\hline 42 & Moldova & 34,810714 & 40,1603 & 37,51735 & 42,6619 & 31,5000 & 52,3699 & 47,1707 & 50,7961 & 31,5000 \\
\hline 44 & Macedonia & 34,12 & 34,49138 & 34,12 & 42,2547 & 34,1200 & 62,2931 & 64,6883 & 61,5516 & 55,9165 \\
\hline
\end{tabular}




\begin{tabular}{|c|c|c|c|c|c|c|c|c|c|c|}
\hline 7 & Brazil & 34,98 & 57,70405 & 45,2428 & 34,9800 & 34,9800 & 71,8150 & 62,6351 & 76,6881 & 34,9800 \\
\hline 12 & Costa Rica & 36,04 & 55,87323 & 48,22179 & 54,5544 & 51,1341 & 50,2251 & 46,0711 & 49,6859 & 36,0400 \\
\hline 43 & Mexico & 37,49 & 51,12929 & 37,49 & 40,3785 & 37,4900 & 56,8647 & 60,7133 & 71,5741 & 37,9340 \\
\hline 66 & Uruguay & 45,460843 & 39,58 & 46,42855 & 39,5800 & 39,5800 & 55,2151 & 46,1444 & 47,0768 & 39,5800 \\
\hline 11 & Colombia & 43,833594 & 40,26 & 43,6059 & 48,8245 & 43,7563 & 50,9612 & 50,1059 & 44,2320 & 40,2600 \\
\hline 37 & Lebanon & 51,632562 & 41,28 & 41,28 & 53,3953 & 47,9188 & 62,6416 & 48,3802 & 60,0132 & 41,2800 \\
\hline 50 & Peru & 41,54 & 44,93124 & 46,2811 & 43,7699 & 43,9571 & 49,1171 & 59,1633 & 69,6916 & 41,5400 \\
\hline 33 & Jordan & 57,27877 & 42,67 & 54,89973 & 56,4964 & 55,9529 & 64,2589 & 53,8926 & 53,6599 & 42,6700 \\
\hline 36 & Kosovo & 45,89 & 55,39768 & 47,9673 & 54,1936 & 45,8900 & 73,1962 & 73,1858 & 79,7636 & 55,9755 \\
\hline 64 & $\begin{array}{c}\text { Trinidad and } \\
\text { Tobago }\end{array}$ & 46,256612 & 53,31624 & 58,46661 & 53,2495 & 46,1000 & 58,7632 & 53,4892 & 46,1000 & 46,1000 \\
\hline 17 & Algeria & 60,995029 & 51,69957 & 63,98131 & 54,9547 & 57,1371 & 62,8556 & 49,7818 & 49,2289 & 48,3600 \\
\hline 16 & $\begin{array}{l}\text { Dominican } \\
\text { Republic }\end{array}$ & 61,28 & 62,53561 & 65,5459 & 65,8370 & 61,2800 & 78,9322 & 78,4211 & 78,3243 & 61,2800 \\
\hline & Mean & 26,341275 & 28,34484 & 27,78411 & 27,5067 & 28,8968 & 40,0066 & 37,12907 & 40,36946 & 26,92325 \\
\hline \multicolumn{2}{|c|}{ Standard Division } & 15,801207 & 16,03278 & 15,04331 & 17,38627 & 13,73561 & 19,49362 & 18,68829 & 18,98823 & 15,199 \\
\hline \multicolumn{2}{|c|}{ Minimum } & 0,4100 & 0,4100 & 1,1797 & 2,3500 & 4,0400 & 2,3500 & 3,3400 & 3,3400 & 2,3500 \\
\hline \multicolumn{2}{|r|}{ Maximum } & 61,28 & 62,53561 & 65,5459 & 65,83699 & 61,28 & 78,9322 & 78,42111 & 79,7636 & 61,28 \\
\hline
\end{tabular}

For hypothetical input 1, the lowest percentage was recommended for Taiwan (China), which was the country closest to total efficiency, while the highest percentage was recommended for the Dominican Republic, which was in last place for success and total efficiency. For this input, a mean percentage reduction of $26.341275 \%$ was recommended for all countries. A slightly above average reduction of $28.08 \%$ was recommended for Turkey.

For hypothetical input 2 , the lowest percentage was recommended for Taiwan (China), which was the country closest to total efficiency, while the highest percentage was recommended for the Dominican Republic, which was in last place for success and total efficiency. For this input, a mean percentage reduction of $28.34484 \%$ was recommended for all countries. A reduction of $52.33819 \%$, which was almost twice the average, was recommended for Turkey.

For hypothetical input 3, the lowest percentage was recommended for Taiwan (China), which was the country closest to total efficiency, while the highest percentage was recommended for the Dominican Republic, which was in last place for success and total efficiency. For this input, a mean percentage reduction of $27.78411 \%$ was recommended for all countries. An above average reduction of $34.74174 \%$ was recommended for Turkey.

For hypothetical input 4, the lowest percentage was recommended for the Netherlands, which was the second closest country to total efficiency, while the highest percentage was recommended for the Dominican Republic, which was in last place for success and total efficiency. For this input, a mean percentage reduction of $27.5067 \%$ was recommended for all countries. A slightly above average reduction of $28.08 \%$ was recommended for Turkey.

For hypothetical input 5, the lowest percentage was recommended for Denmark, which was the fourth closest country to total efficiency, while the highest percentage was recommended for the Dominican Republic, which was in last place for success and total efficiency. For this input, a mean percentage reduction of $28.8968 \%$ was recommended for all countries. An above average reduction of $41.4593 \%$ was recommended for Turkey.

For hypothetical input 6 , the lowest percentage was recommended for the Netherlands, which was the second closest country to total efficiency, while the highest percentage was recommended for the Dominican Republic, which was in last place for success and total efficiency. For this input, a mean percentage reduction of $40.0066 \%$ was recommended for all countries. A well above average reduction of $64.3816 \%$ was recommended for Turkey.

For hypothetical input 7, the lowest percentage was recommended for Austria, which was the third closest country to total efficiency, while the highest percentage was recommended for the Dominican Republic, which was in last place for success and total efficiency. For this input, a mean percentage reduction of $37.12907 \%$ was recommended for all countries. A well above average reduction of $69.6966 \%$ was recommended for Turkey.

For hypothetical input 8, the lowest percentage was recommended for Austria, which was the third closest country to total efficiency, while the highest percentage was recommended for the Kosovo, which was in fourth from last place for total efficiency. For this input, a mean percentage reduction of $40.36946 \%$ was recommended for all countries. A well above average reduction of $67.3763 \%$ was recommended for Turkey.

For hypothetical input 9, the lowest percentage was recommended for the Netherlands, which was the second closest country to total efficiency, while the highest percentage was recommended for the Dominican Republic, which was in last place for success and total efficiency. For this input, a mean percentage reduction of $26.92325 \%$ was recommended for all countries. An above average reduction of $37.6027 \%$ was recommended for Turkey.

\section{Discussion}

In this study, based on the data of the PISA 2015 report, the science achievement of students in 68 countries was evaluated with reference to educational inputs, which are considered to affect their success. 15 of the countries included in the study (Canada, Switzerland, Estonia, Finland, Hong Kong (China), Hungary, Iceland, Japan, Korea, Lithuania, Macao (China), Poland, Singapore, Slovenia and Vietnam) were totally efficient. Based on this, it can be said that these countries used their inputs and efforts efficiently and conducted their activities on a suitable scale (Lorcu, 2008). They were able to successfully manage the factors regarded as educational inputs in the PISA 2015 report, namely "student behaviours preventing learning", "teacher behaviours preventing learning", "lack of educational materials", "lack of teaching staff", "professional development", "teacher participation", "curriculum development", "total number of science teachers in school" and "science-specific resource index (total)". In this way, they increased achievement in science. Examining the literature, studies have been conducted that support this finding. In a study conducted by Lavonen and Laaksonen (2009) based on the PISA 2006 data, it was concluded that the source of Finnish students' success in science lessons was practical work in class and the students' deductions. A knowledge-based society, development of educational equality and decisive power on a local level, 
and teacher education were regarded as the most important education policy issues underlying students' high performance in science lessons in the PISA 2006 report. Similarly, in a study conducted by McConney et al. (2014) based on the PISA 2006 data, it was stated that science achievement of students in Australia, Canada and New Zealand was related to how much they experienced inquiry-based teaching and learning. In Tang (2015) study, the results of the analyses made based on the PISA 2006 data for 5,995 students in the USA and Taiwan revealed that with their science teaching-learning activities, students in the USA had more opportunities to learn science than students in Taiwan. It was revealed that in the USA, students who had a higher socioeconomic level had more opportunities with regard to reform-based science learning activities. Moreover, it was determined that students' higher socioeconomic level bore no relation to reform-based science learning in Taiwan.

The data in the PISA 2015 report were also evaluated for different countries according to science teachers' perceptions school principals' perceptions and implementation of the teaching programme. In their study, Chi et al. (2018) used the science performance of students in Beijing, Shanghai, Jiangsu and Guangdong, and background research data for PISA 2015, and the results revealed that rather than teacher support, disciplinary climate had a positive effect on the relationship between inquiry-based science activities and students' science achievement for both genders. In Oztürk (2018) study based on the PISA 2015 data, it was determined that for different socioeconomic levels there were significant relationships between scientific literacy and environmental awareness, and between scientific literacy and environmental optimism. In a study by Susongko and Afrizal (2018) using the PISA 2015 data for Indonesian students, it was concluded that environmental awareness was related to the students' enjoyment of learning science, their self-efficacy in science, their instrumental motivation, inquiry-based instruction in science learning, and their science proficiency and epistemic beliefs. In Lau and Lam (2017) study, according to the PISA 2015 data, adaptive instruction, teacher-directed instruction and interactive application were positively correlated with science performance in all regions. The regions apart from Japan and Korea tended to have a high frequency of teacher-directed instruction facilitated by more or less authoritative discussion in class.

It was seen that of the countries having total efficiency, the three countries mostly shown as references were Japan, Poland and Estonia. In Lewis (1995) study, it is argued that Japanese schools support their students' academic success because they meet the students' needs, thereby supporting strong, positive emotional ties between students and their school, and this supports the finding obtained in this study that Japan was one of the country's most often taken as an example. Zawistowska (2014) considers that the greatest impact on the increase in Poland's PISA scores was the educational reform made in 1999. In this reform, it is considered that the most important change affecting PISA data was the introduction of assessments other than multiple choice. It may be considered that these changes in the education system in Poland are a reason why Poland was shown as a reference for countries that were not totally efficient.

It was revealed that the countries furthest from being totally efficient were Jordan, Kosovo, Trinidad and Tobago, Algeria and the Dominican Republic. In a study conducted by Al-Amoush et al. (2011) it was concluded that science teachers and preservice science teachers in Jordan tended to use traditional teaching methods, based on which, it can be said that the fact that the country was among the most unsuccessful in the PISA data may be related to procedures in the teaching process. In a study made by Al-Amoush et al. (2014) teaching-learning beliefs of German, Turkish and Jordanian preservice teachers were determined and compared. These findings correspond to the research findings made by Al-Amoush et al. (2011). The preference of the Jordanian teacher candidates was the general educational approach, which was the teacher-centred approach. The preference of the German teacher candidates was the modern educational approach. The situation of the Turkish preservice teachers was between these two extremes. Although they had an approach close to the traditional educational approach, they had more modern educational beliefs than those of the Jordanian teacher candidates.

It was concluded that apart from New Zealand, all countries had increasing returns to scale. In other words, an input of 1 unit in the inputs resulted in an output greater than 1 in the outputs. Fernandez et al. (2008) emphasised that New Zealand needed to update its physics curriculum. The justification for this was shown to be the lack of communication between teachers and curriculum designers. In support of the study findings, criticisms were made by Buabeng (2015) to the effect that physics teachers in New Zealand were not trained to be adequately equipped, and that they were not sufficiently qualified to be able to use investigative teaching methods or techniques, or to make correct assessments, in their lessons.

In this study, the results also revealed that there was no relationship between being a totally effective country and geographic proximity. In a study by Taht and Must (2010) the PISA data of five neighbouring countries, namely Russia, Latvia, Estonia, Sweden and Finland were evaluated. Differences were determined among scores. It was considered that these differences may be due to differences in cultural influences on personality or to national educational and social policies. Similarly, in a study carried out by Herbst and Wojciuk (2017) it was stressed that the neighbouring countries of the Czech Republic, Hungary, Poland and Slovakia had institutional differences in their education systems and that differences between national approaches towards educational reforms were reflected especially in education centralisation, school autonomy, accountability and financial mechanisms.

It was seen that Turkey lagged behind many countries in terms of total efficiency. This situation shows that there are problems related to the use of educational inputs. In a study by Anil (2011) in which the 2006 PISA data were used, "time" was the variable that best predicted science success and the factor most clearly determining success. The other factors that predicted science achievement were "environment", "education" and "attitudes", respectively.

Bakir et al. (2015) determined that success rates in PISA data were related to countries' socioeconomic statuses. It was stated that Turkey's low achievement levels were due to the fact that national income is also low. In a study by Kahraman and Celik (2017) an attempt was made to determine Turkish students' success and sources in the PISA 2012 data. It was found that attendance at nursery school, school starting age, mother's employment status, parents' educational level and numbers of computers and books at home affected student success. Having a working mother and high school starting age had a negative effect on student success. On the other hand, attendance at nursery school, parents with a high educational level and a high number of books and computers in the home had a 
positive impact on students' achievement. Moreover, it was determined that the sociocultural and environmental locations of the students affected their success.

Based on these findings, it can be recommended that in order for countries whose science success was determined as low in the PISA report to increase their success, they should manage their educational inputs and take reference countries that are suitable for themselves as examples. It can be recommended that when organising and implementing their education programmes, they should take their educational inputs and successful countries into consideration. It can also be recommended to researchers that they undertake similar studies using the PISA data, and that they examine the reasons for the findings of this study with different methods.

\section{References}

Aaronson, D., L. Barrow and W. Sander, 2007. Teachers and student achievement in the Chicago public high schools. Journal of Labor Economics, 25(1): 95-135.Available at: https://doi.org/10.1086/508733.

Al-Amoush, S., S. Markic, M. Usak, M. Erdogan and I. Eilks, 2014. Beliefs about chemistry teaching and learning-a comparison of teachers'and student teachers'beliefs from jordan, turkey and germany. International Journal of Science and Mathematics Education, 12(4): 767-792.Available at: https://doi.org/10.1007/s10763-013-9435-7.

Al-Amoush, S.A., S. Markic, I. Abu-Hola and I. Eilks, 2011. Jordanian prospective and experienced chemistry teachers' beliefs about teaching and learning and their potential role for educational reform. Science Education International, 22(3): 185-201.

Anil, D., 2011. Investigation of factors influencing Turkey's PISA 2006 science achievement with structural equation modelling. Educational Sciences: Theory and Practice, 11(3): 1261-1266.

Baeten, M., E. Kyndt, K. Struyven and F. Dochy, 2010. Using student-centred learning environments to stimulate deep approaches to learning: Factors encouraging or discouraging their effectiveness. Educational Research Review, 5(3): 243-260.Available at: https://doi.org/10.1016/j.edurev.2010.06.001.

Bakir, S., H. Demirel and Y.E. Yilmaz, 2015. PISA scores from 2003 to 2012: A comparison of Turkey with the three countries which have been successful in each term in field of science. Procedia-Social and Behavioral Sciences, 174: 2733-2742.Available at: https://doi.org/10.1016/j.sbspro.2015.01.960.

Banker, R.D., A. Charnes and W.W. Cooper, 1984. Some models for estimating technical and scale inefficiencies in data envelopment analysis. Management Science, 30(9): 1078-1092.Available at: https://doi.org/10.1287/mnsc.30.9.1078.

Bennett, J., F. Lubben and S. Hogarth, 2007. Bringing science to life: A synthesis of the research evidence on the effects of context-based and STS approaches to science teaching. Science Education, 91(3): 347-370.Available at: https://doi.org/10.1002/sce.20186.

Buabeng, I., 2015. Teaching and learning of Physics in New Zealand high schools. PhD Thesis, University of Canterbury, New Zealand.

Bybee, R.W., 2014. NGSS and the next generation of science teachers. Journal of Science Teacher Education, 25(2): 211-221.Available at: https://doi.org/10.1007/s10972-0 14-9381-4.

Cairns, D. and S. Areepattamannil, 2019. Exploring the relations of inquiry-based teaching to science achievement and dispositions in 54 countries. Research in Science Education, 49(1): 1-23.Available at: https://doi.org/10.1007/s 11 165-017-9639-x.

Charnes, A., W.W. Cooper and E. Rhodes, 1978. Measuring the efficiency of decision making units. European Journal of Operational Research, 2(6): 429-444.Available at: https://doi.org/10.1016/0377-2217(78)90138-8.

Chi, S., X. Liu, Z. Wang and S. Won Han, 2018. Moderation of the effects of scientific inquiry activities on low SES students' PISA 2015 science achievement by school teacher support and disciplinary climate in science classroom across gender. International Journal of Science Education, 4O(11): 1284-1304.Available at: https://doi.org/10.1080/09500693.2018.1476742.

Clermont, C.P., H. Borko and J.S. Krajcik, 1994. Comparative study of the pedagogical content knowledge of experienced and novice chemical demonstrators. Journal of Research in Science Teaching, 31(4): 419-441.Available at: https://doi.org/10.1002/tea.3660310409.

Cooper, W.W., S. Li, L.M. Seiford, K. Tone, R.M. Thrall and J. Zhu, 2001. Sensitivity and stability analysis in DEA: Some recent developments. Journal of Productivity Analysis, 15(3): $217-246$.

Davis, E.A., D. Petish and J. Smithey, 2006. Challenges new science teachers face. Review of Educational Research, 76(4): 607-65 1.Available at: https://doi.org/10.3102/00346543076004607.

Durán-Narucki, V., 2008. School building condition, school attendance, and academic achievement in New York City public schools: A mediation model. Journal of Environmental Psychology, 28(3): 278-286.Available at: https://doi.org/10.1016/j.jenvp.2008.02.008.

Dyson, R.G., R. Allen, A.S. Camanho, V.V. Podinovski, C.S. Sarrico and E.A. Shale, 2001. Pitfalls and protocols in DEA. European Journal of Operational Research, 132(2): 245-259.Available at: https://doi.org/10.1016/s0377-2217(00)00149-1.

Evagorou, M., S. Erduran and T. Mäntylä, 2015. The role of visual representations in scientific practices: From conceptual understanding and knowledge generation to 'seeing'how science works. International Journal of STEM Education, 1(2): 1-13.Available at: https://doi.org/10.1186/s40594-015-0024-x.

Fernandez, T., G. Ritchie and M. Barker, 2008. A sociocultural analysis of mandated curriculum change: The implementation of a new senior physics curriculum in New Zealand schools. Journal of Curriculum Studies, 4O(2): 187-213.Available at: https://doi.org/10.1080/00220270701313978.

Gislason, N., 2010. Architectural design and the learning environment: A framework for school design research. Learning Environments Research, 13(2): 127-145.Available at: https://doi.org/10.1007/s 10984-010-9071-x.

Harris, D.N. and T.R. Sass, 2011. Teacher training, teacher quality and student achievement. Journal of Public Economics, 95(7-8): 798812.Available at: https://doi.org/10.1016/j.jpubeco.2010.11.009.

Herbst, M. and A. Wojciuk, 2017. Common legacy, different paths: The transformation of educational systems in the Czech Republic, Slovakia, Hungary and Poland. Compare: A Journal of Comparative and International Education, 47(1): 118-132.Available at: https://doi.org/10.1080/03057925.2016.1153410.

Hill, N.E. and L.C. Taylor, 2004. Parental school involvement and children's academic achievement: Pragmatics and issues. Current Directions in Psychological Science, 13(4): 161-164.Available at: https://doi.org/10.1111/j.0963-7214.2004.00298.x.

Hodson, D., 1988. Experiments in science and science teaching. Educational Philosophy and Theory, 20(2): 53-66.Available at: https://doi.org/10.1111/j.1469-5812.1988.tbo0144.x.

Holbrook, J. and M. Rannikmae, 2007. The nature of science education for enhancing scientific literacy. International Journal of Science Education, 29(11): 1347-1362.Available at: https://doi.org/10.1080/09500690601007549.

Huppert, J., S.M. Lomask and R. Lazarowitz, 2002. Computer simulations in the high school: Students' cognitive stages, science process skills and academic achievement in microbiology. International Journal of Science Education, 24(8): 803-821.Available at: https://doi.org/10.1080/09500690110049150.

Jeynes, W.H., 2007. The relationship between parental involvement and urban secondary school student academic achievement: A metaanalysis. Urban Education, 42(1): 82-1 10.Available at: https://doi.org/10.1177/0042085906293818

Kahraman, Ü. and K. Celik, 2017. Analysis of PISA 2012 results in terms of some variables. Journal of Human Sciences, 14(4): 47974808.Available at: https://doi.org/10.14687/jhs.v 14i4.5136.

Kirschner, P.A., J. Sweller and R.E. Clark, 2006. Why minimal guidance during instruction does not work: An analysis of the failure of constructivist, discovery, problem-based, experiential, and inquiry-based teaching. Educational Psychologist, 41(2): 75-86.Available at: https://doi.org/10.1207/s15326985ep4102_1.

Koretsky, M.D., M. Vauras, C. Jones, T. Iiskala and S. Volet, 2019. Productive disciplinary engagement in high- and low-outcome student groups: Observations from three collaborative science learning contexts. Research in Science Education, 49(138): 1-24.Available at: https://doi.org/10.1007/s11165-019-9838-8.

Lau, K.-c. and T.Y.-p. Lam, 2017. Instructional practices and science performance of 10 top-performing regions in PISA 2015. International Journal of Science Education, 39(15): 2128-2 149.Available at: https://doi.org/10.1080/09500693.2017.1387947. 
Lavonen, J. and S. Laaksonen, 2009. Context of teaching and learning school science in Finland: Reflections on PISA 2006 results. Journal of Research in Science Teaching, 46(8): 922-944.Available at: https://doi.org/10.1002/tea.20339.

Lewis, C.C., 1995. The roots of Japanese educational achievement: Helping children develop bonds to school. Educational Policy, 9(2): 129151.Available at: https://doi.org/10.1177/0895904895009002003.

Lorcu, F., 2008. Data envelopment analysis (DEA) to evaluate the effectiveness of Turkey and the European Union countries in the health field. Unpublished PhD Thesis, Istanbul University, Institute of Social Sciences, Istanbul.

Maltese, A.V., C.S. Melki and H.L. Wiebke, 2014. The nature of experiences responsible for the generation and maintenance of interest in STEM. Science Education, 98(6): 937-962.Available at: https://doi.org/10.1002/sce.21132.

Maxwell, L.E., 2016. School building condition, social climate, student attendance and academic achievement: A mediation model. Journal of Environmental Psychology, 46: 206-2 16.Available at: https://doi.org/10.1016/j.jenvp.2016.04.009.

McConney, A., M.C. Oliver, A. WOODS-McCONNEY, R. Schibeci and D. Maor, 2014. Inquiry, engagement, and literacy in science: A retrospective, cross-national analysis using PISA 2006. Science Education, 98(6): 963-980.Available at: https://doi.org/10.1002/sce.21135.

Mulholland, J. and J. Wallace, 1996. Breaking the cycle: Preparing elementary teachers to teach science. Journal of Elementary Science Education, 8(1): 17-38.Available at: https://doi.org/10.1007/bfo3173739.

Osborne, J., 2014. Teaching scientific practices: Meeting the challenge of change. Journal of Science Teacher Education, 25(2): 177196.Available at: https://doi.org/10.1007/s 10972-014-9384-1.

Osborne, J., S. Simon and S. Collins, 2003. Attitudes towards science: A review of the literature and its implications. International Journal of Science Education, 25(9): 1049-1079.Available at: https://doi.org/10.1080/0950069032000032199.

Oztürk, Ö., 2018. Using PISA 2015 data to analyze how the scientific literacy of students from different socioeconomic levels can be predicted by environmental awareness and by environmental optimism. (Doctoral Dissertation, Bilkent University).

Palmer, D.H., 2001. Factors contributing to attitude exchange amongst preservice elementary teachers. Science Education, 86: 122138.Available at: https://doi.org/10.1002/sce.10007.

Rivera, M.D. and S.R. Lopez, 2019. Some pennies are more equal than others: Inequitable school facilities investment in San Antonio, Texas. Education Policy Analysis Archives, 27(16): 1-34.Available at: http://dx.doi.org/10.14507/epaa.27.4191.

Rockoff, J.E., 2004. The impact of individual teachers on student achievement: Evidence from panel data. American Economic Review, 94(2): 247-252.Available at: https://doi.org/10.1257/0002828041302244.

Rothstein, J., 2010. Teacher quality in educational production: Tracking, decay, and student achievement. The Quarterly Journal of Economics, 125(1): 175-214.Available at: https://doi.org/10.1162/qjec.2010.125.1.175.

Sheldrake, R., T. Mujtaba and M.J. Reiss, 2017. Science teaching and students' attitudes and aspirations: The importance of conveying the applications and relevance of science. International Journal of Educational Research, 85(1): 167-183.Available at: https://doi.org/10.1016/j.ijer.2017.08.002.

Stohr-Hunt, P.M., 1996. An analysis of frequency of hands-on experience and science achievement. Journal of Research in Science Teaching, 33(1): 101-109.Available at: https://doi.org/10.1002/(sici)1098-2736(199601)33:1<101::aid-tea6>3.0.co;2-z.

Susongko, P. and T. Afrizal, 2018. The determinant factors Analysis of Indonesian students' environmental awareness in PISA 2015. Indonesian Science Education Journal, 7(4): 407-419.Available at: https://doi.org/10.15294/jpii.v7i4.10684.

Taht, K. and O. Must, 2010. Are the links between academic achievement and learning motivation similar in five neighbouring countries? Trames Journal of the Humanities and Social Sciences, 14(3): 271-281.Available at: https://doi.org/10.3176/tr.2010.3.04.

Tang, N.E., 2015. The effect of reform-based science teaching on SES-associated achievement gap on Pisa 2006: A comparative study of the United States and Taiwan. (Doctoral Dissertation, University of Missouri--Columbia).

Teig, N., R. Scherer and T. Nilsen, 2018. More isn't always better: The curvilinear relationship between inquiry-based teaching and student achievement in science. Learning and Instruction, 56(1): 20-29.Available at: https://doi.org/10.1016/j.learninstruc.2018.02.006.

Zawistowska, A., 2014. The black box of the educational reforms in Poland: What caused the improvement in the PISA scores of polish students? Polish Sociological Review, 187(3): 333-350. 